\title{
Sodium nitrate decreases agrin-induced acetylcholine receptor clustering
}

\author{
Jess Jarosz, Cullen White and Wade A. Grow*
}

\begin{abstract}
Background: Humans are exposed to nitrate predominantly through diet with peak plasma concentrations within an hour after ingestion, but additional exposure is obtained from the environment, and minimally through de novo synthesis. Higher nitrate consumption has been associated with methemoglobinemia, spontaneous abortions, atherosclerosis, myocardial ischemia, septic and distressed lung, inflammatory bowel disease, amyotrophic lateral sclerosis, and neural tube defects. However, skeletal muscle development has not been examined.

Methods: C2C12 skeletal muscle cell cultures were maintained, myoblasts were fused into myotubes, and then cultures were exposed to motor neuron derived agrin to enhance acetylcholine receptor (AChR) clustering. Untreated cultures were compared with cultures exposed to sodium nitrate at concentrations ranging from $10 \mathrm{ng} / \mathrm{mL}-100 \mu \mathrm{g} / \mathrm{mL}$.

Results: The results reported here demonstrate that $1 \mu \mathrm{g} / \mathrm{mL}$ sodium nitrate was sufficient to decrease the frequency of agrin-induced AChR clustering without affecting myotube formation. In addition, concentrations of sodium nitrate of $1 \mu \mathrm{g} / \mathrm{mL}$ or $100 \mu \mathrm{g} / \mathrm{mL}$ decreased gene expression of the myogenic transcription factor myogenin and AChR in correlation with the agrin-induced AChR clustering data.

Conclusions: These results reveal that sodium nitrate decreases the frequency of agrin-induced AChR clustering by a mechanism that includes myogenin and AChR gene expression. As a consequence sodium nitrate may pose a risk for skeletal muscle development and subsequent neuromuscular synapse formation in humans.
\end{abstract}

Keywords: AChR, Agrin, C2C12, Myogenin, Sodium nitrate

\section{Background}

For over 70 years methemoglobinemia in infants has been linked to nitrate consumption $[1,2]$. Normally a small percentage of hemoglobin exists as methemoglobin (about $1-2 \%$, which is due to genetic factors or chemical exposure and typically does not result in health issues. When that percentage increases, methemoglobinemia may result, decreasing the oxygen carrying capacity and distribution by the affected hemoglobin. Nitrate reduced to nitrite will oxidize ferrous iron causing a shift to methemoglobin which has been linked to methemoglobinemia in infants whose formula was made with well water [1]. Not all infants developed methemoglobinemia and so it is believed

\footnotetext{
* Correspondence: wgrowx@midwestern.edu

Department of Anatomy, Midwestern University, 19555 N. 59th Avenue, Glendale, AZ 85308, USA

that the involvement of nitrate or nitrite is a cofactor in this disease [2].

Correlations between nitrate intake and gestational complications such as increased spontaneous abortions have been noted [3]. Studies in animals have shown that nitrate, nitrite and $N$-nitroso compounds are all capable of crossing the placenta [4-6], and there have been cases of abortions in pigs pastured or housed in feedlots with oats and rape containing high levels of nitrates, $0.53 \%$ and $5.52 \%$ respectively [7]. Studies have considered whether or not nitrate is involved in spontaneous abortions in humans $[3,8]$. A study in Bulgaria found that women with high nitrate exposure suffered from one or more complications, with $67 \%$ having anemia, $23 \%$ toxemia, and $33 \%$ spontaneous abortions or premature delivery. Of the population studied only $16 \%$ had a normal pregnancy [9]. 
Gastric generation of nitrotyrosines from increased nitrite intake have been detectable in vivo and have been found in tissues associated with multiple pathologies: atherosclerosis, myocardial ischemia, septic and distressed lung, inflammatory bowel disease, and amyotrophic lateral sclerosis [10, 11]. In addition, higher rates of neural tube defects have been reported for fetuses of pregnant women who took nitrosatable drugs or drank water with higher levels of nitrate [12].

Humans are exposed to nitrate predominantly through diet with peak plasma concentrations $60 \mathrm{~min}$ after ingestion [13]. Some nitrate exposure is obtained from the environment, and additionally (though minimally) through de novo synthesis. In the diet consumption is primarily from fruits and vegetables, which comprise $60-80 \%$ of the nitrate ingested [14]. A secondary source of dietary consumption is cured meats. Sodium nitrate and its reduced form sodium nitrite are used by the meat industry to prevent microbial growth (namely c. botulinum) and retain the color of preserved and cured meats [14]. Dietary intake is estimated at $50-140 \mathrm{mg} /$ day in Europe and 40-100 mg/day in the United States [15].

De novo synthesis of nitrate has been estimated to range from 500 to $1000 \mu \mathrm{mol} /$ day $[16,17]$. In a study where human subjects consumed a diet with slightly less than average nitrate levels, endogenous nitrate was reported at an average of $870 \mu \mathrm{mol} /$ day [18]. The higher estimate of $1000 \mu \mathrm{mol} /$ day translates into $62 \mathrm{mg} /$ day, and when combined with estimates of dietary intake [15], the total nitrate exposure could be as high as $200 \mathrm{mg} /$ day in Europe and $160 \mathrm{mg} /$ day in the United States. Another study using ${ }^{15} \mathrm{NO}_{3}{ }^{-}$determined that endogenous nitrate production occurred at all levels of ingestion, however at higher levels of intake endogenous production was masked [16]. The level of nitrate intake per day varies depending on age, gender, race/ ethnicity, BMI and level of education [19].

Skeletal muscle development in fetuses of pregnant women exposed to high nitrate levels has not been examined. During skeletal muscle development, myoblasts proliferate and fuse to form multinucleated myotubes. Acetylcholine receptors (AChR) will cluster spontaneously but aggregation increases upon exposure to motor neuron derived agrin [20-22], as AChRs become part of the postsynaptic component of the neuromuscular synapse. In addition, the myogenic regulatory factor myogenin activates genes for AChR subunits [23, 24], suggesting that myogenic regulatory factors like myogenin are intricately linked to the development of the postsynaptic component. Exposure to nicotine, caffeine, ethanol, and mercury have been demonstrated to decrease AChR clustering in $\mathrm{C} 2 \mathrm{C} 12$ myotubes [25-28], whereas methoxychlor has been demonstrated to decrease myotube formation by slowing myoblast proliferation without affecting AChR clustering [29].
The objective of the current study was to investigate whether sodium nitrate affects skeletal muscle development, specifically the events of myoblast fusion into myotubes and AChR clustering. And if there is an effect, does sodium nitrate mediate that effect by interfering with myogenin or AChR expression. Skeletal muscle cell cultures, such as the $\mathrm{C} 2 \mathrm{C} 12$ cell line derived from mouse hindlimb, provide simplified systems for studying development of the postsynaptic component of the neuromuscular synapse [30,31]. The $\mathrm{C} 2 \mathrm{C} 12$ cell culture model has proven useful for asking fundamental questions concerned with muscle development and neuromuscular synapse formation, and is ideal for examining how sodium nitrate might interfere with these developmental events. The results reported here demonstrate that $1 \mu \mathrm{g} / \mathrm{mL}$ sodium nitrate was sufficient to decrease the frequency of agrin-induced AChR clustering without affecting myotube formation. In addition, sodium nitrate decreased myogenin and $\mathrm{AChR}$ gene expression in correlation with the agrin-induced AChR clustering data.

\section{Methods}

\section{Cell culture maintenance}

C2C12 myoblasts were derived from mouse hind limb (gift from H. Gordon, University of Arizona) [30, 31], and are commonly used for skeletal muscle cell culture experiments. They are ideal for studying myoblast fusion to form myotubes, and acetylcholine receptor (AChR) clustering. For normal maintenance of $\mathrm{C} 2 \mathrm{C} 12$ cell culture, myoblasts were first plated in growth medium (GM) on $10 \mathrm{~cm}$ plates at approximately $20 \%$ confluence. GM consists of Dulbecco's modified Eagle's medium (DMEM) plus $20 \%$ fetal bovine serum, $0.5 \%$ chick embryo extract and $100 \mathrm{U} / \mathrm{mL}$ penicillin. Fresh GM was added daily, and myoblast cultures were split into new plates at approximately $60 \%$ confluence. For formation of myotubes, myoblasts were plated in GM on $22 \times 22 \mathrm{~mm}$ cover slips that had been flamed in 200-proof ethanol and placed in 6-well plates. Fresh GM was added daily. After $48 \mathrm{~h}$ in GM, myoblast cultures typically reached $90 \%$ confluence, and cultures were then switched to differentiation medium (DM). DM consists of DMEM plus $2 \%$ horse serum and $100 \mathrm{U} / \mathrm{mL}$ penicillin. Fresh DM was added daily as myoblasts fused to form myotubes, and cultures were maintained for $72 \mathrm{~h}$ in DM. All cultures were exposed to $10 \mathrm{ng} / \mathrm{mL}$ agrin (R\&D Systems) for the last $16 \mathrm{~h}$ of $72 \mathrm{~h}$ in DM to induce AChR clustering. Some cultures were exposed to $10 \mathrm{ng} / \mathrm{mL}-100 \mu \mathrm{g} / \mathrm{mL}$ sodium nitrate $\left(\mathrm{NaNO}_{3}\right.$; Sigma-Aldrich) for the last $48 \mathrm{~h}$ of $72 \mathrm{~h}$ in DM. A $1 \mathrm{~g} / \mathrm{mL} \mathrm{NaNO}_{3}$ stock solution was prepared in $\mathrm{DM}$ and then serial dilutions were performed to achieve the treatment concentrations. It would be difficult to correlate nitrate dietary intake and endogenous nitrate 
production with nitrate treatment in cell culture. At best cell culture might mirror fetal exposure to toxins in maternal blood to some degree. Therefore, a range of $\mathrm{NaNO}_{3}$ concentrations were tested in cell culture to investigate any effect on AChR clustering, myotube formation, and myogenin and AChR gene expression.

\section{Acetylcholine receptor clustering assay}

AChRs were labeled by the binding of $\alpha$-bungarotoxin conjugated to tetramethyl rhodamine (Molecular Probes) [32]. Cultures were incubated in the toxin-containing medium for $30 \mathrm{~min}$ at $37{ }^{\circ} \mathrm{C}$ to label AChRs after $72 \mathrm{~h}$ in DM. The cover slips were rinsed three times with room temperature phosphate buffered saline (PBS), fixed for 10 min with $2 \%$ paraformaldehyde in PBS, rinsed three times with PBS, dehydrated in cold methanol for 5 min at $-20{ }^{\circ} \mathrm{C}$, and mounted on microscope slides in Vectashield Mounting Medium for Fluorescence (Vector Laboratories). For some experiments the mounting medium contained 4'6-diamidino-2-phenylindole (DAPI) to visualize nuclei. AChR clusters were visualized with an IX70 Olympus inverted microscope under the 20X objective (yielding a total magnification of 200X), and fluorescent images were captured as high-resolution JPG files with an Olympus camera with Magnafire digital imaging software. Bright clusters of AChRs were observed on all aspects of myotubes in fluorescent images. AChR clusters were counted from 25 images captured from each cover slip using ImageJ software. One cover slip was analyzed for each treatment group in each replicate experiment. These data were utilized to assay agrin-induced AChR clustering in untreated cultures, or after exposure to $10 \mathrm{ng} / \mathrm{mL}-100 \mu \mathrm{g} / \mathrm{mL} \mathrm{NaNO}_{3}$ for the last $48 \mathrm{~h}$ of $72 \mathrm{~h}$ in DM. Comparisons of untreated cultures with cultures exposed to $\mathrm{NaNO}_{3}$ were analyzed by Student's $t$-test to determine statistically different results at $p<0.05$. Representative images were assembled into Fig. 2.

\section{Myotube formation index}

Cell cultures were visualized with an IX70 Olympus inverted microscope under the 20X objective (yielding a total magnification of 200X), and representative phase contrast and DAPI images were captured as highresolution JPG files with an Olympus camera with Magnafire digital imaging software. Composite images were created through GNU Image Manipulation Program (GIMP 2) which was used to identify myoblasts (defined as cells with one or two nuclei) or myotubes (defined as cells with three or more nuclei). DAPI staining was used to observe and count nuclei. These images were utilized to quantify myotube formation by modifying a myoblast fusion index paradigm [33] into a myotube formation index used in our laboratory $[26,28,29]$. Six composite images were analyzed for untreated cultures, and five composite images each for cultures exposed to $1 \mu \mathrm{g} / \mathrm{mL} \mathrm{NaNO}_{3}$ or $10 \mu \mathrm{g} / \mathrm{mL}$ $\mathrm{NaNO}_{3}$ for the last $48 \mathrm{~h}$ of $72 \mathrm{~h}$ in DM. The myotube formation index was then calculated as the fraction of nuclei in myotubes, with the data displayed in Table 1.

\section{Western blots}

To assay for protein levels of the myogenic regulatory factor myogenin or AChR, myotube cultures were divided into untreated cultures, and those that had been exposed to $10 \mathrm{ng} / \mathrm{mL}, 1 \mu \mathrm{g} / \mathrm{mL}$, or $100 \mu \mathrm{g} / \mathrm{mL} \mathrm{NaNO}$ for the last $48 \mathrm{~h}$ of $72 \mathrm{~h}$ in DM. Myotube cultures were rinsed twice with calcium- and magnesium-free PBS (CMF-PBS), scraped off in RIPA complete lysis buffer (containing PMSF, sodium orthovanadate, and protease inhibitors), agitated for $30 \mathrm{~min}$ on ice, and then centrifuged at $13,000 \mathrm{~g}$ for $2 \mathrm{~min}$ to create pellets containing insoluble materials such as organelles and extracellular matrix. The extracted supernatant was then frozen. At a later time samples were thawed, a BCA protein assay was performed to determine the concentration of protein in each sample, and samples were boiled for $5 \mathrm{~min}$ in sample buffer to reduce and denature proteins. Then samples were separated by electrophoresis on a $10 \%$ polyacrylamide gel (Bio-Rad) and transferred to a nitrocellulose membrane. The membranes were blocked with $5 \%$ milk in TBS-T, with some membranes probed for $16 \mathrm{~h}$ at $4{ }^{\circ} \mathrm{C}$ with a mouse monoclonal antibody to myogenin (sc-12732; Santa Cruz Biotechnology) at 1:1000 in blocking solution, and then probed by a goat anti-mouse secondary antibody (926-32210; Li-Cor) at 1:10,000 in blocking solution for $30 \mathrm{~min}$. Other membranes were probed for $16 \mathrm{~h}$ at $4{ }^{\circ} \mathrm{C}$ with a rabbit polyclonal antibody to AChR (SC-11372; Santa Cruz Biotechnology) at 1:1000 in blocking solution, and then probed by a goat anti-rabbit secondary antibody (926-68071; Li-Cor) at 1:10,000 in blocking solution for $30 \mathrm{~min}$. The resultant western blot was then visualized with the Odyssey CLx, a near infrared imaging system. It uses solid state diode lasers to excite at 685 and $785 \mathrm{~nm}$. For scanning, the western blot was placed on the glass surface of the odyssey and covered with a rubber mat. In the Li-Cor software a box was created to define the scanning area of the blot. The 700 and 800 channels were chosen and low quality image quality and $169 \mu \mathrm{m}$ resolution was checked before "start scan" was pressed. As a loading

Table 1 Myotube formation index

\begin{tabular}{|c|c|c|c|c|}
\hline & $\begin{array}{l}\text { Total } \\
\text { nuclei }\end{array}$ & $\begin{array}{l}\text { Nuclei in } \\
\text { myotubes }\end{array}$ & $\begin{array}{l}\text { Nuclei in } \\
\text { myoblasts }\end{array}$ & $\begin{array}{l}\text { Fraction of nuclei } \\
\text { in myotubes }\end{array}$ \\
\hline Untreated $(n=6)$ & 2440 & 2177 & 263 & 0.8922 \\
\hline $1 \mu \mathrm{g} / \mathrm{ml} \mathrm{NaNO}{ }_{3}(n=5)$ & 2372 & 2088 & 284 & 0.8803 \\
\hline $10 \mu \mathrm{g} / \mathrm{ml} \mathrm{NaNO}(n=5)$ & 1917 & 1653 & 264 & 0.8623 \\
\hline
\end{tabular}


control, all samples were also probed with a mouse monoclonal antibody to actin (sc-8432; Santa Cruz Biotechnology). The ratio of myogenin or AChR signal to actin signal could then be calculated and compared across treatment groups, along with the percent reduction in this ratio for treatment groups compared to untreated cultures. The western blot data and agrin-induced AChR clustering data is displayed in Table 2.

\section{Results}

\section{$\mathrm{NaNO}_{3}$ decreases the frequency of agrin-induced AChR clusters}

AChRs cluster spontaneously with a baseline frequency on $\mathrm{C} 2 \mathrm{C} 12$ myotubes and this clustering is increased with agrin treatment [20-22]. C2C12 cell cultures were switched from GM to DM at $90 \%$ confluence, $10 \mathrm{ng} / \mathrm{mL}$ agrin was added for the last $16 \mathrm{~h}$ in DM, and myotubes were examined for AChR clustering after $72 \mathrm{~h}$ in DM. Some cultures were left untreated (control cultures), while others were exposed to $10 \mathrm{ng} / \mathrm{mL}-100 \mu \mathrm{g} / \mathrm{mL} \mathrm{NaNO}_{3}$ for the last $48 \mathrm{~h}$ of $72 \mathrm{~h}$ in DM. For each experiment one cover slip was analyzed for each treatment group or control. AChR clusters were counted from 25 images captured from each cover slip using ImageJ software. One cover slip was analyzed for each treatment group in each replicate experiment, with typical data sets reported (Figs. 1 and 2). $1 \mu \mathrm{g} / \mathrm{mL} \mathrm{NaNO}_{3}$ was sufficient to decrease the frequency of agrin-induced AChR clustering, with statistical significance at $p<0.05$ using Student's $t$-test.

\section{$\mathrm{NaNO}_{3}$ has no effect on myotube formation}

Myotube formation was quantified by modifying a myoblast fusion index paradigm [33] into a myotube formation index used in our laboratory $[26,28,29]$. Composite images were created through GNU Image Manipulation Program (GIMP 2) which was used to identify myoblasts (defined as cells with one or two nuclei) or myotubes (defined as cells with three or more nuclei), and then analyzed as described in the Methods and Fig. 3 legend. The myotube formation index was then calculated as the fraction of nuclei in myotubes and presented in Table 1 as a summary of the data collected. The fraction of nuclei in myotubes was unaffected by exposure to $1 \mu \mathrm{g} / \mathrm{mL} \mathrm{NaNO}_{3}$ or $10 \mu \mathrm{g} / \mathrm{mL} \mathrm{NaNO}_{3}$ for the last $48 \mathrm{~h}$ of $72 \mathrm{~h}$ in DM.

\section{$\mathrm{NaNO}_{3}$ decreases myogenin and $\mathrm{AChR}$ gene expression}

The myogenic regulatory factor myogenin activates genes for AChR subunits [23, 24]. This suggests that myogenic regulatory factors like myogenin are intricately linked to the development of the AChR postsynaptic component of the neuromuscular synapse. Therefore a decrease in the frequency of agrin-induced AChR clusters could have many causes. First, $\mathrm{NaNO}_{3}$ may decrease AChR gene expression, directly reducing $\mathrm{AChR}$ available for agrin-induced clustering of AChRs. Second, $\mathrm{NaNO}_{3}$ may decrease myogenin expression, making less myogenin available to activate genes for $\mathrm{AChR}$ subunits, indirectly reducing $\mathrm{AChR}$ available for agrin-induced clustering of AChRs. Alternately, a decrease in myogenin gene expression could lead to decreased activation of other genes necessary for $\mathrm{AChR}$ clustering with or without an effect on AChR gene expression. Finally, $\mathrm{NaNO}_{3}$ may decrease $\mathrm{AChR}$ clustering through a mechanism that does not affect the level of AChR gene expression. Western blots were used to measure the amount of myogenin protein and $\mathrm{AChR}$ protein. $\mathrm{C} 2 \mathrm{C} 12$ cell cultures were exposed to $10 \mathrm{ng} / \mathrm{mL}, 1 \mu \mathrm{g} / \mathrm{mL}$, or $100 \mu \mathrm{g} / \mathrm{mL} \mathrm{NaNO}_{3}$ for the last $48 \mathrm{~h}$ of $72 \mathrm{~h}$ in DM, with representative western blots presented (Fig. 4). $\mathrm{NaNO}_{3}$ decreased myogenin and $\mathrm{AChR}$ gene expression in correlation with the agrin-induced AChR clustering data. For the representative experiment in Fig. 4, this correlation is detailed in Table 2.

Table 2 Comparison of $\mathrm{NaNO}_{3}$ effects

\begin{tabular}{|c|c|c|c|c|}
\hline Myogenin expression & Myogenin expression signal & Actin expression signal & Myogenin/Actin ratio & Percent compared with untreated \\
\hline Untreated & 1170 & 1630 & 0.7178 & \\
\hline $1 \mu \mathrm{g} / \mathrm{ml} \mathrm{NaNO} \mathrm{N}_{3}$ & 1360 & 2130 & 0.6385 & $89 \%$ \\
\hline $100 \mu \mathrm{g} / \mathrm{ml} \mathrm{NaNO} 3$ & 1030 & 2640 & 0.3902 & $54 \%$ \\
\hline AChR expression & AChR expression signal & Actin expression signal & AChR/Actin ratio & Percent compared with untreated \\
\hline Untreated & 2490 & 3610 & 0.6898 & \\
\hline $1 \mu \mathrm{g} / \mathrm{ml} \mathrm{NaNO} \mathrm{Na}_{3}$ & 1910 & 4590 & 0.4161 & $60 \%$ \\
\hline $100 \mu \mathrm{g} / \mathrm{ml} \mathrm{NaNO}{ }_{3}$ & 2340 & 9320 & 0.2511 & $36 \%$ \\
\hline Agrin-induced AChR clustering & & & $\begin{array}{l}\text { AChR clusters per field } \\
\text { of view }\end{array}$ & Percent compared with untreated \\
\hline Untreated & & & 19.24 & \\
\hline $1 \mu \mathrm{g} / \mathrm{ml} \mathrm{NaNO}{ }_{3}$ & & & 9.14 & $48 \%$ \\
\hline $100 \mu \mathrm{g} / \mathrm{ml} \mathrm{NaNO}{ }_{3}$ & & & 7.42 & $39 \%$ \\
\hline
\end{tabular}




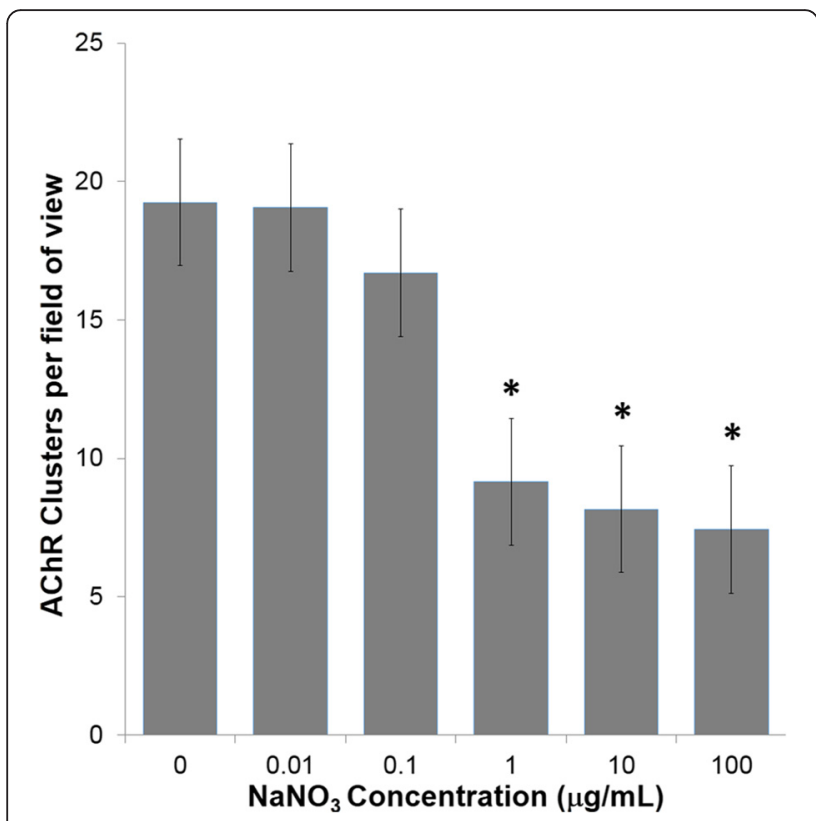

Fig. $1 \mathrm{NaNO}_{3}$ decreases the frequency of agrin-induced AChR clusters. Frequency of agrin-induced AChR clusters were quantified by analyzing fluorescent images from agrin-induced cultures that were untreated or were exposed to $10 \mathrm{ng} / \mathrm{mL}-100 \mu \mathrm{g} / \mathrm{mL} \mathrm{NaNO}$ for the last $48 \mathrm{~h}$ of $72 \mathrm{~h}$ in DM. The histogram reveals that exposure to $1 \mu \mathrm{g} / \mathrm{mL} \mathrm{NaNO}{ }_{3}$ was sufficient to decrease agrin-induced $A C h R$ clusters relative to untreated cultures, using Student's $t$-test at $p<0.05 .\left(^{*}\right)$ statistically decreased from untreated cultures. Error bar indicates standard error of the mean (s.e.m.)

\section{Discussion}

The results reported here demonstrate that sodium nitrate decreases the frequency of agrin-induced acetylcholine receptor (AChR) clustering in correlation with a decrease in myogenin and $A C h R$ gene expression. This suggests that sodium nitrate may interfere with normal developmental events by initially decreasing myogenin gene expression, which causes a decrease in AChR gene expression, and ultimately results in fewer AChRs available to cluster in response to agrin stimulation.

Myogenin is one of several myogenic transcription factors that guide skeletal muscle development. Myogenin directly activates rapsyn gene expression [34] and the genes for AChR subunits [23, 24]. Rapsyn is one of several postsynaptic molecules that is essential for the formation of AChR clusters during neuromuscular synapse formation [35]. Another is a muscle specific kinase (MuSK) that is essential for the signaling events that precede AChR clustering [36-39]. These signaling events are initiated when motor neuron derived agrin binds to lowdensity lipoprotein receptor-related protein (Lrp4) [40, 41] to stimulate tyrosine phosphorylation of MuSK [38] and the subsequent signaling pathway that includes the tyrosine phosphorylation of the AChR $\beta$ subunit leading to increased AChR clustering [42, 43]. Suppression of Lrp4 gene expression decreases agrin binding activity, agrin-induced MuSK tyrosine phosphorylation, and agrininduced AChR clustering [41].
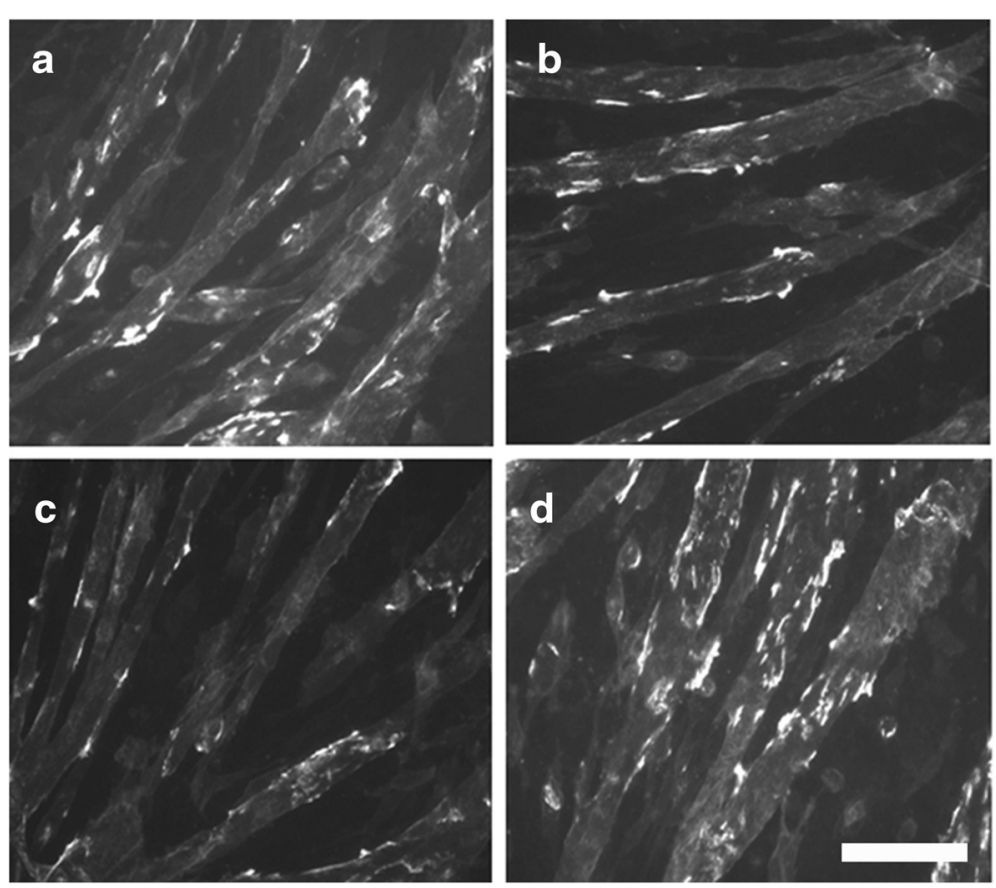

Fig. 2 Examples of cell cultures exposed to $\mathrm{NaNO}_{3}$. Fluorescent images were captured from agrin-induced cultures that were untreated (a), or exposed for the last $48 \mathrm{~h}$ of $72 \mathrm{~h}$ in $\mathrm{DM}$ to $10 \mu \mathrm{g} / \mathrm{mL} \mathrm{NaNO}$ (b), $1 \mu \mathrm{g} / \mathrm{mL} \mathrm{NaNO}$ (c), or $100 \mathrm{ng} / \mathrm{mL} \mathrm{NaNO}$ (d). Fluorescent areas are clusters of AChRs. Scale bar $=100 \mu \mathrm{m}$ 

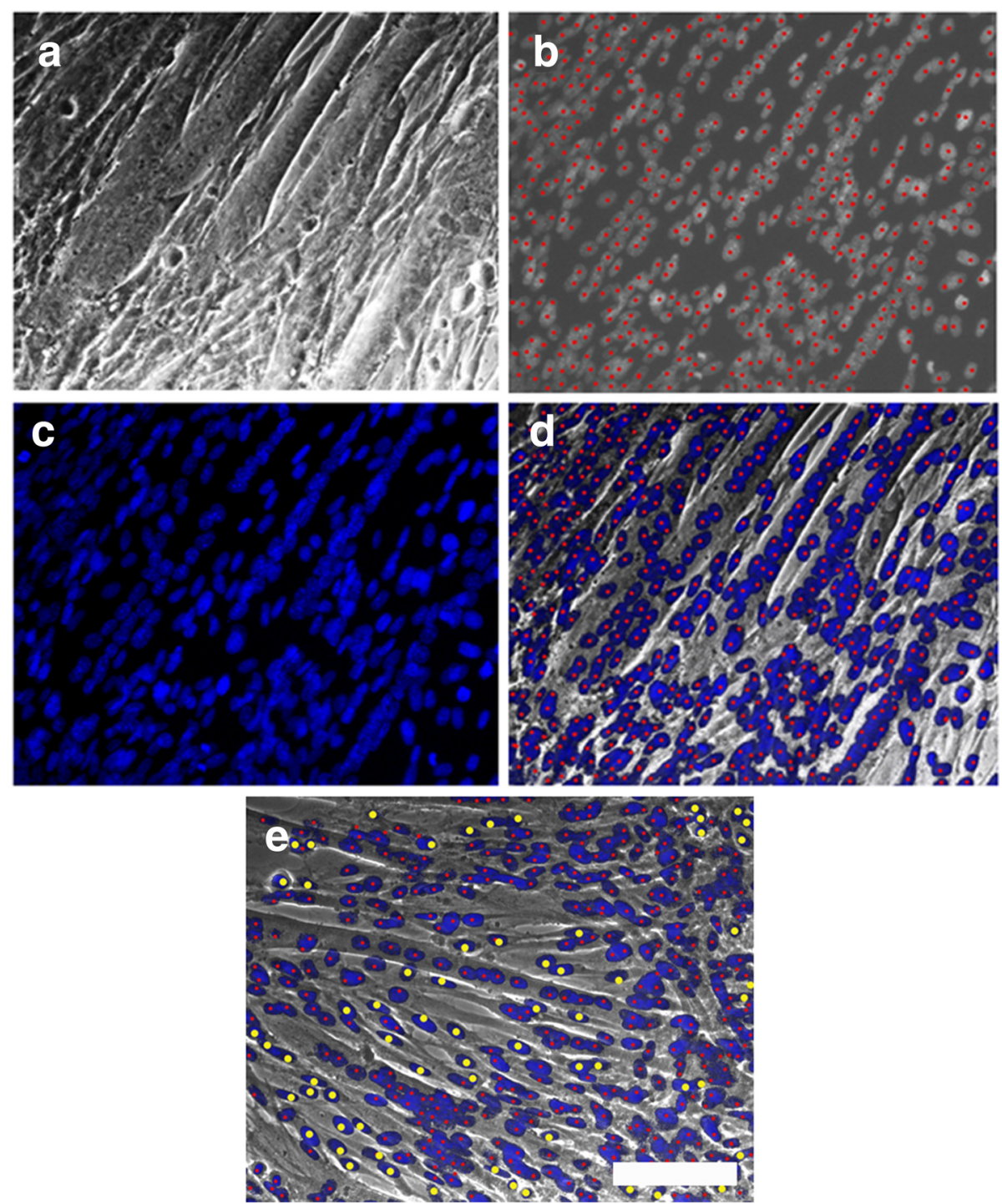

Fig. 3 Composite images were created through GNU Image Manipulation Program (GIMP 2) which was used to identify myoblasts (defined as cells with one or two nuclei) or myotubes (defined as cells with three or more nuclei). Phase contrast images were captured to visualize myotubes and myoblasts (a), while fluorescent images were captured to label nuclei with dots (b) and visualize nuclei with DAPI (c). These layers were combined into a composite image (d). An example of a composite image with nuclei in myoblasts labeled with yellow (large) dots and nuclei in myotubes labeled with red (small) dots to allow for quantification of fraction of nuclei in myotubes is included (e). Scale bar $=100 \mu \mathrm{m}$

In the data reported in Table 2, when compared with untreated cell cultures, treatment with $1 \mu \mathrm{g} / \mathrm{ml}$ sodium nitrate decreased myogenin gene expression to $89 \%$ of the untreated level, and treatment with $100 \mu \mathrm{g} / \mathrm{ml}$ sodium nitrate decreased myogenin gene expression to $54 \%$ of the untreated level. This correlated with a consequent decrease in AChR gene expression to $60 \%$ of the untreated level with $1 \mu \mathrm{g} / \mathrm{ml}$ sodium nitrate treatment, and a decrease to $36 \%$ of the untreated level with $100 \mu \mathrm{g} / \mathrm{ml}$ sodium nitrate treatment. Decreases in myogenin and AChR gene expression also correlated with decreased agrin-induced AChR clustering, where treatment with $1 \mu \mathrm{g} / \mathrm{ml}$ sodium nitrate decreased agrin- induced AChR clustering to $48 \%$ of the untreated level, and treatment with $100 \mu \mathrm{g} / \mathrm{ml}$ sodium nitrate decreased agrin-induced AChR clustering to $39 \%$ of the untreated level. This data shows that the level of agrin-induced AChR clustering is directly correlated with the level of $\mathrm{AChR}$ gene expression, supporting the interpretation that with sodium nitrate treatment fewer AChRs are available to cluster in response to agrin stimulation. Finally, with sodium nitrate treatment of $0.01 \mu \mathrm{g} / \mathrm{ml}$ agrin-induced $\mathrm{AChR}$ clustering and myogenin gene expression were unaffected, while AChR gene expression was decreased to $66 \%$ of the untreated level (data not shown), suggesting $\mathrm{AChR}$ gene expression is more sensitive to sodium nitrate 


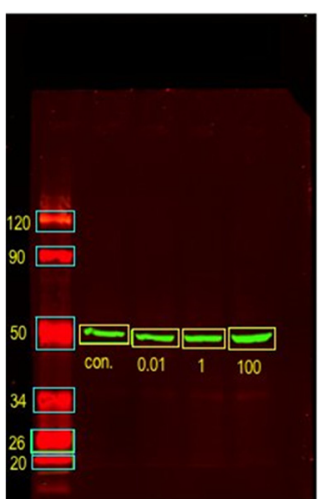

Actin

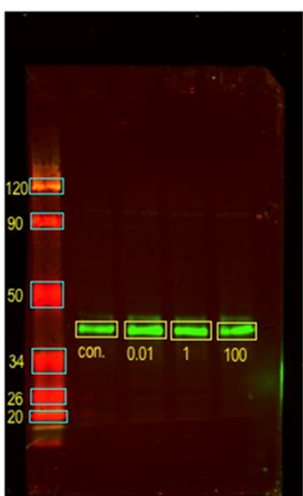

Myogenin

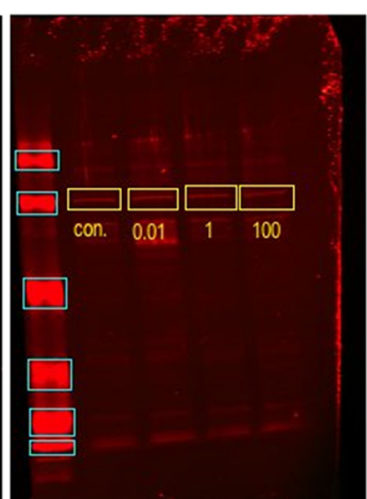

AChR

Fig. $4 \mathrm{NaNO}_{3}$ decreased myogenin and AChR gene expression in correlation with the agrin-induced AChR clustering data. Untreated agrin-induced cultures were compared with cultures exposed to $10 \mathrm{ng} / \mathrm{mL}, 1 \mu \mathrm{g} / \mathrm{mL}$, or $100 \mu \mathrm{g} / \mathrm{mL} \mathrm{NaNO}$ for the last $48 \mathrm{~h}$ of $72 \mathrm{~h}$ in DM. Cultures were assayed for the amount of myogenin or AChR protein and compared with an actin control. The data correlating these two effects of $\mathrm{NaNO}_{3}$ is detailed in Table 2. These results demonstrate that $\mathrm{NaNO}_{3}$ decreases the frequency of agrin-induced AChR clustering by a mechanism that causes decreased myogenin and AChR gene expression

levels than myogenin gene expression and that AChR gene expression is not the sole determinant of agrininduced AChR clustering.

Myogenin was previously shown to be essential for myoblast differentiation $[44,45]$. In the data reported here, concentrations of sodium nitrate as high as $10 \mu \mathrm{g} / \mathrm{ml}$ had no effect on myotube formation. The fraction of nuclei in myotubes was 0.8922 for untreated cultures, 0.8803 for cultures treated with $1 \mu \mathrm{g} / \mathrm{ml}$ sodium nitrate, and 0.8623 for cultures treated with $10 \mu \mathrm{g} / \mathrm{ml}$ sodium nitrate. In contrast, concentrations as low as $1 \mu \mathrm{g} / \mathrm{ml}$ were sufficient to decrease agrin-induced AChR clustering. This may reflect a difference in sensitivity to myogenin levels between myotube formation and agrin-induced AChR clustering. Alternately, this may reflect the time sequence, since myotube formation occurs prior to synapse formation and AChR clustering in normal skeletal muscle development. A previous study showed that treatment of $\mathrm{C} 2 \mathrm{C} 12$ cells with myogenin antibodies also decreased agrin-induced AChR clustering without affecting myotube formation [46].

The reduction in $\mathrm{AChR}$ clustering caused by sodium nitrate could have a functional outcome similar to common neuromuscular disorders. As an example, patients with the autoimmune disease myasthenia gravis have muscle weakness due to a decrease in functional AChRs. In contrast, patients with muscular dystrophy have muscle weakness due to neuromuscular synapses that have reduced or absent postsynaptic molecules other than AChRs. However the functional outcome is the same, muscle weakness. The data reported here suggests that any disease process that affects myogenin gene expression could also lead to muscle weakness due to a decrease in AChR clustering at neuromuscular synapses caused by a decrease in
AChR gene expression. For further inquiry it might be useful to replicate these experiments using other cell lines including human muscle cell lines to see if the results are universal across species.

\section{Conclusions}

The results reported here demonstrate that $1 \mu \mathrm{g} / \mathrm{mL}$ sodium nitrate was sufficient to decrease the frequency of agrin-induced AChR clustering without affecting myotube formation. In addition, sodium nitrate decreased myogenin and AChR gene expression in correlation with the agrin-induced AChR clustering data. These results demonstrate that sodium nitrate decreases the frequency of agrin-induced AChR clustering by a mechanism that includes myogenin and $\mathrm{AChR}$ gene expression. As a consequence sodium nitrate may pose a risk for skeletal muscle development and subsequent neuromuscular synapse formation in humans.

\section{Competing interests}

The authors declare that they have no competing interests.

\section{Authors' contributions}

JJ participated in study design, cell culture maintenance, AChR clustering assays, myotube formation index, and helped draft the manuscript. CW participated in cell culture maintenance, AChR clustering assays, and western blots. WG participated in study design and helped draft the manuscript. All authors read and approved the final manuscript.

\section{Acknowledgments}

This work was supported by Midwestern University funding through the Biomedical Sciences Program (Jess Jarosz) and the Office of Research and Sponsored Programs (Cullen White and Wade A. Grow). In addition, Senior Research Associate Kelly Ezell provided technical expertise. A preliminary account of this work has appeared in abstract form [47].

Received: 18 November 2015 Accepted: 14 April 2016

Published online: 01 May 2016 


\section{References}

1. Comly HH. Cyanosis in infants caused by nitrates in well water. JAMA. 1945;129:112-6.

2. Fewtrell L. Drinking-water nitrate, methemoglobinemia, and global burden of disease: A discussion. Environ Health Perspect. 2004;112:1371-4.

3. Schmitz JT. Methemoglobinemia - a cause of abortions? A preliminary report. Obstet Gynecol. 1961;17:413-5.

4. Gruener N, Shuval HI, Behroozi K, Cohen S, Shechter H. Methemoglobinemia induced by transplantal passage of nitrate in rats. Bull Environ Contam Toxicol. 1973;9:44-8.

5. Fan AM, Willhite CC, Book SA. Evaluation of the nitrate drinking water standard with reference to infant methemoglobinemia and potential reproductive toxicity. Regul Toxicol Pharmacol. 1987;7:135-48.

6. Brunning-Fan CS, Kaneene JB. The effects of nitrate, nitrite and $\mathrm{N}$-nitroso compounds on human health: A review. Vet Hum Toxicol. 1993;35:521-38.

7. Case AA. Abortion in swine due to excess nitrate. Journal of the American Veterinary Medical Association. 1957;131-226.

8. Skrivan J. Methemoglobinemia in pregnancy (clinical and experimental study). Acta Universitatis Carolinea Medica (Praha). 1971;17:123-61.

9. Tabacova S, Balabaeva L, Little RE. Maternal exposure to exogenous nitrogen compounds and complications of pregnancy. Arch Environ Health. 1997:52:341-7

10. Archer MC. Mechanisms of action of N-nitroso compounds. Cancer Survivor 1989:8:241-50.

11. Beckman JS, Koppenol WH. Nitric oxide, superoxide, and peroxynitrite: The good, the bad, and ugly. Am J Cell Physiol. 1996;271:C1424-37.

12. Brender JD, Olive JM, Felkner M, Suarez L, Marckwardt W, Hendricks KA. Dietary nitrites and nitrates, nitrosatable drugs, and neural tube defects. Epidemiology. 2004;15:330-6.

13. McKnight GM, Smith LM, Drummond RS, Duncan CW, Golden M, Benjamin N. Chemical synthesis of nitric oxide in the stomach from dietary nitrate in humans. Gut. 1997:40:211-4

14. Ysart G, Miller P, Barrett G, Farrington D, Lawrence P, Harrison N. Dietary exposures to nitrate in the UK. Food Addit Contam. 1999:16:521-32.

15. Mensinga TT, Speijers GJ, Meulenbelt J. Health implications of exposure to environmental nitrogenous compounds. Toxicol Rev. 2003:22:41-51.

16. Green LC, De Luzuriaga KR, Wagner DA, Rand W, Istfan N, Young VR, Tanenbaum SR. Nitrate biosynthesis in man. Proc Natl Acad Sci. $1981 ; 78: 7764-8$

17. Tanenbaum SR, Fett D, Young VR, Land PD, Bruce WR. Nitrite and nitrate are formed by endogenous synthesis in the human intestine. Science. 1978;200:1487-9.

18. Lee K, Greger JL, Consaul JR, Graham KL, Chinn BL. Nitrate, nitrite balance, and de novo synthesis of nitrate in humans consuming cured meats. Am J Clin Nutr. 1986:44:188-94.

19. Griesenbeck JS, Brender JD, Sharkey JR, Steck MD, Huber JC, Rene AA, McDonald TJ, Romitti PA, Canfield MA, Langlois PH, Suarez L. Maternal characteristics associated with the dietary intake of nitrates, nitrites, and nitrosamines in women of child-bearing age: a cross-sectional study. Environ Health. 2010;9:10

20. Godfrey EW, Nitkin RM, Wallace BG, Rubin LL, McMahan UJ. Components of Torpedo electric organ and muscle that cause aggregation of acetylcholine receptors on cultured muscle cells. J Cell Biol. 1984;99:615-27.

21. Nitkin RM, Smith MA, Magill C, Fallon JR, Yao YM, Wallace BG, McMahan UJ. Identification of agrin, a synaptic organizing protein from Torpedo electric organ. J Cell Biol. 1987;105:2471-8.

22. McMahan UJ. The agrin hypothesis. Cold Spring Harb Symp Quant Biol. 1990;55:407-18.

23. Tang H, Sun Z, Goldman D. CaM kinase II-dependent suppression of nicotinic acetylcholine receptor delta-subunit promoter activity. J Biol Chem. 2001;276:26057-65.

24. Tang H, Macpherson P, Argetsinger LS, Cieslak D, Suhr ST, Carter-Su C, Goldman D. CaM kinase II-dependent phosphorylation of myogenin contributes to activity-dependent suppression of $\mathrm{nAChR}$ gene expression in developing rat myotubes. Cell Signal. 2004;16:551-63.

25. Ferayorni AJ, Gunville CF, Grow WA. Nicotine decreases agrin signaling and acetylcholine receptor clustering in C2C12 myotube culture. J Neurobiol. 2004;60:51-60

26. Miller TJ, Grow WA. Mercury decreases the frequency of induced but not spontaneous clustering of acetylcholine receptors. Cell Tissue Res. 2004;316:211-9.
27. Kordosky-Herrera K, Grow WA. Caffeine and nicotine decrease acetylcholine receptor clustering in C2C12 myotube culture. Cell Tissue Res. 2009;335:341-8.

28. Owen DB, Chamberlain KT, Shishido S, Grow WA. Ethanol decreases agrin-induced acetylcholine receptor clustering in C2C12 myotube culture. Toxicol in Vitro. 2010;24:645-51.

29. Steffens BW, Batia LM, Baarson CJ, Choi CKC, Grow WA. The pesticide methoxychlor decreases myotube formation in cell culture by slowing myoblast proliferation. Toxicol in Vitro. 2007;21:770-81.

30. Yaffe D, Saxel O. Serial passaging and differentiation of myogenic cells isolated from dystrophic mouse muscle. Nature. 1977;270:725-7.

31. Blau HM, Pavlath GK, Hardeman EC, Chiu CP, Silberstein L, Webster SG, Miller SC, Webster C. Plasticity of the differentiated state. Science. 1985;230:758-66.

32. Ravdin P, Axelrod D. Fluorescent tetramethyl rhodamine derivatives of alpha-bungarotoxin: preparation, separation, and characterization. Anal Biochem. 1977;80:585-92.

33. Rando TA, Blau HM. Primary mouse myoblast purification, characterization, and transplantation for cell-mediated gene therapy. J Cell Biol. 1994:125:1275-87.

34. Blais A, Tsikitis M, Acosta-Alvear D, Sharan R, Kluger T, Dynlacht BD. An initial blueprint for myogenic differentiation. Genes Dev. 2005;19:553-69.

35. Gautam M, Noakes PG, Mudd J, Nichol M, Chu GC, Sanes JR, Merlie JP. Failure of postsynaptic specialization to develop at neuromuscular junctions of rapsyn-deficient mice. Nature. 1995;377:232-6.

36. Bowen DC, Park JS, Bodine S, Stark JL, Valenzuela DM, Stitt TN, Yancopoulos GD, Lindsay RM, Glass DJ, DiStefano PS. Localization and regulation of MuSK at the neuromuscular junction. Dev Biol. 1998;199:309-19.

37. Gautam M, DeChiara TM, Glass DJ, Yancopoulos GD, Sanes JR. Distinct phenotypes of mutant mice lacking agrin, MuSK, or rapsyn. Brain Res Dev Brain Res. 1999;114:171-8.

38. Glass DJ, Bowen DC, Stitt TN, Radziejewski C, Bruno J, Ryan TE, Gies DR, Shah S, Mattsson K, Burden SJ, DeStefano PS, Valenzuela DM, DeChiara TM, Yancopolous GD. Agrin acts via a MuSK receptor complex. Cell. 1996;85:513-23.

39. Sugiyama JE, Glass DJ, Yancopoulos GD, Hall ZW. Laminin-induced acetylcholine receptor clustering: an alternative pathway. J Cell Biol. 1997;139:181-91.

40. Kim N, Stiegler AL, Cameron TO, Hallock PT, Gomez AM, Huang JH, Hubbard SR, Dustin ML, Burden SJ. Lrp4 is a receptor for agrin and forms a complex with MuSK. Cell. 2008;135:334-42.

41. Zhang B, Luo S, Wang Q, Suzuki T, Xiong WC, Mei L. Lrp4 serves as a co-receptor of agrin. Neuron. 2008:60:285-97.

42. Ferns M, Deiner M, Hall Z. Agrin-induced acetylcholine receptor clustering in mammalian muscle requires tyrosine phosphorylation. J Cell Biol. 1996;132:937-44

43. Wallace BG, Qu Z, Huganir RL. Agrin induces phosphorylation of the nicotinic acetylcholine receptor. Neuron. 1991;6:869-78.

44. Hasty P, Bradley A, Morris JH, Edmondson DG, Venuti JM, Olson EN, Klein WH. Muscle deficiency and neonatal death in mice with a targeted mutation in the myogenin gene. Nature. 1993;364:501-6.

45. Nabeshima Y, Hanaoka K, Hayasaka M, Esumi E, Li S, Nonaka I, Nabeshima Y. Myogenin gene disruption results in perinatal lethality because of severe muscle defect. Nature. 1993:364:532-5.

46. Ball MK, Campbell DH, Ezell K, Henley JB, Standley PR, Grow WA. Antibody to MyoD or myogenin decreases acetylcholine receptor clustering in $\mathrm{C} 2 \mathrm{C} 12$ myotube culture. Cell Bio. 2013;2:138-48.

47. White C, Grow W. Sodium nitrate decreases agrin-induced AChR clustering. FASEB J. 2015;29:874.1. 